Section Editor

Mitchell S.V. Elkind,

MD, MS

\title{
Emerging Subspecialties in Neurology: Public policy fellowships
}

Nassim Zecavati, MD, $\mathrm{MPH}$

Sarah Song, MD, MPH

Jill Giordano Farmer, $\mathrm{DO}, \mathrm{MPH}$

Address correspondence and reprint requests to Dr. Nassim Zecavati, Pediatric Neurology, Georgetown University Hospital, Department of Pediatrics, 3800 Reservoir Road, NW, 2PHC, Washington, DC 20007 Nassim.Zecavati@gunet.georgetown.edu
"Now, more than ever, American science must enlighten American statecraft." This statement made by former Secretary of State Colin Powell eloquently describes the dynamic that exists between physicians and policy makers. The importance of policy-making and its effects on the field of neurology recently became evident with the passage of the health care reform bill. The controversial Patient Protection and Affordable Care Act (ACA), signed into law on March 23, 2010, enacts the most significant health care reform since the creation of Medicare in 1965. Neurologists can interface with the legislative branch of the US government and participate in the lawmaking process through a number of advocacy opportunities and fellowships which we describe here.

PUBLIC POLICY FELLOWSHIPS There are a number of public policy fellowships available to physicians including one available exclusively to adult and child neurologists. Many organizations offer fellowships, several of which have a long history of training physicians and scientists for careers in public policy and advocacy. One of the largest of these organizations is the American Association for the Advancement of Science (AAAS). The AAAS manages and administers a number of science and technology policy fellowships with the goal of enabling physicians, scientists, and engineers to participate in and contribute to the federal policy-making process. There are 2 types of fellowships available through AAAS: congressional fellowships and executive branch fellowships. Approximately 30 partner societies fund Congressional fellowships that place fellows in either the US House of Representatives or the US Senate. This includes the Viste Neurology Public Policy Fellowship (NPPF) sponsored jointly by the American Academy of Neurology (AAN), the Child Neurology Society, and the American Neurological Association (ANA). Congressional fellowships, in particular, are highly competitive as they allow neurologists to draft and shape legislation of interest to members of Congress. Fellows are often allowed to take the lead on the legislation of their choice with guidance and mentoring from Congressional staff. Recent legislation crafted by Neurology Public Policy Fellows includes several Affordable Care Act provisions, one of which (sec. 3013) mandates the development of a series of outcome measures to reliably reflect the efficacy and efficiency of the patient experience from the care delivered. Unlike Congressional fellows, Executive branch fellows are hosted by federal agencies such as the Department of Defense and are funded by the hosting office. These fellows work on broad topics of interest to the administration such as education and the environment.

The NPPF has successfully placed neurologists on Capitol Hill for over a decade. ${ }^{1}$ Previous Neurology Public Policy Fellows have served in offices across Capitol Hill in both House and Senate offices and for Democrats and Republicans. These fellows have served on the staffs of Senator Charles Grassley (R-IA), ranking member of the Senate Finance Committee, Senator Michael Enzi (R-WY), ranking member of the Committee on Health, Education, Labor, and Pensions, and Senator Jeff Bingaman (D-NM), chairman of the Senate Committee on Energy and Natural Resources, all key players in health reform. Further information regarding previous NPPF graduates is available on the AAN Web site. ${ }^{1}$ After completion of fellowship, a neurologist may opt to return to clinical practice or continue his or her advocacy efforts on behalf of the AAN/Child Neurology Society/ANA. Alternatively, a fellow may pursue a full-time position in the Administration or in Congress. A previous NPPF graduate, Dr. Terri Postma, accepted a position at the Centers for Medicare and Medicaid (CMS) in 2010, where she is currently Senior Advisor and Medical Officer for the Performance-Based Payment Policy Staff, tasked with developing and implementing new policies regarding Accountable Care Organizations (ACOs) and other value-based purchasing reforms. Dr.

From the Department of Pediatrics (N.Z.), Georgetown University School of Medicine, Washington, DC; UCLA Stroke Center and Department of Neurology (S.S.), American Heart Association/Pharmaceutical Roundtable-Spina Outcomes Research Center, Los Angeles, CA; and Department of Neurology (J.G.F.), Georgetown University Hospital, Washington, DC.

Disclosure: Author disclosures are provided at the end of the article. 
Table Summary of advocacy opportunities and health policy fellowships available to neurologists ${ }^{2}$

\begin{tabular}{|c|c|c|c|c|}
\hline Advocacy opportunity & Duration & Eligible applicants ${ }^{a}$ & Annual salary & Web site and contact information \\
\hline Neurology on the Hill & 2 days & $\begin{array}{l}\text { Neurology residents and practicing } \\
\text { neurologists }\end{array}$ & $\begin{array}{l}\text { Reimbursement for travel and expenses } \\
\text { provided }\end{array}$ & www.aan.com/go/advocacy/active/noh \\
\hline $\begin{array}{l}\text { Palatucci Advocacy } \\
\text { Leadership Forum }\end{array}$ & 4 days & $\begin{array}{l}\text { Neurology residents and practicing } \\
\text { neurologists }\end{array}$ & $\begin{array}{l}\text { Reimbursement for travel and expenses } \\
\text { provided }\end{array}$ & www.aan.com/go/advocacy/active/palf \\
\hline $\begin{array}{l}\text { Viste Neurology Public } \\
\text { Policy Fellowship }\end{array}$ & 1 year & $\begin{array}{l}\text { Neurology residents and practicing } \\
\text { neurologists }\end{array}$ & $\$ 90,000$ & www.aan.com/go/advocacy/active/viste \\
\hline White House Fellowship & 1 year & College graduates & $\$ 100,000$ & www.whitehouse.gov/about/fellows \\
\hline $\begin{array}{l}\text { American Public Health } \\
\text { Association }\end{array}$ & $1-2$ years & Residents and physicians & $\$ 65,000$ & www.apha.org/advocacy/fellowship \\
\hline $\begin{array}{l}\text { Health and Aging Policy } \\
\text { Fellowship }\end{array}$ & $9-12$ months & Health care professionals & $\$ 120,000$ & www.healthandagingpolicy.org \\
\hline $\begin{array}{l}\text { Winston Health Policy } \\
\text { Fellowship }\end{array}$ & $12-16$ months & Master's degree or higher & $\$ 47,580$ & www.winstonfellowship.com \\
\hline $\begin{array}{l}\text { RWJ Foundation Clinical } \\
\text { Scholars Program }\end{array}$ & $2-3$ years & Physicians & $\$ 62,000$ & rwjcsp.unc.edu \\
\hline
\end{tabular}

a Eligible neurology residents includes child neurology trainees.

${ }^{b}$ Fellowship jointly sponsored by the American Academy of Neurology, Child Neurology Society, and American Neurological Association.

Postma states that her participation in the development of the ACA taught her "the language to approach issues in policy, understand the political pressure points and the process by which laws are implemented." Postma goes on to say that the NPPF "was a stepping stone to my role at CMS where I am working to implement delivery system reforms designed to increase quality and reduce unnecessary expenditures for Medicare beneficiaries." While the NPPF experience varies from year to year, all fellows spend 1 year on Capitol Hill immersed in the dayto-day activities of the legislative branch of the US government.

Other prominent policy fellowships on Capitol Hill that are available to health professionals include the Robert Wood Johnson (RWJ) Foundation Clinical Scholars Program, the Winston Health Policy Fellowship, and the Health and Aging Policy Fellowship (table). ${ }^{2}$ These programs are unique in that they offer an insider's perspective of the political process, mentoring from experienced Congressional staff, and a professional network that is long-lasting. The RWJ Fellowship, for example, is offered through several partnering institutions, including UCLA and Yale University. Fellows have the opportunity to take classes in research methods and health policy, and have the option to obtain Masters' degrees in health services, epidemiology, or public health. Neurologists who graduate from the RWJ program have gone on to prominent positions in academia, industry, and are involved in public health initiatives globally.

ADVOCACY OPPORTUNITIES While health policy fellowships offer the most hands-on experience in federal policy-making, there are also other opportunities to become effective and knowledgeable advo- cates. An opportunity provided by the AAN to Academy members is the annual Donald M. Palatucci Advocacy Leadership Forum (PALF). Over the course of 3 days, PALF combines media training with brainstorming and legislative training. Each neurologist develops an action plan surrounding an issue that he or she is passionate about. After the Forum, advocates are able to continue to work on their individual action plans with the support of the AAN and other advocate alumni. Examples of successful PALF projects include educating the public about the positive effects of art therapy in patients with $\mathrm{AD}$ and increasing awareness of sports concussions.

Neurology on the Hill (NOH) is another unique opportunity available through the AAN to become involved in policy-making issues. $\mathrm{NOH}$ enables a select group of neurologists to converge in Washington, DC, to meet with lawmakers face to face and discuss issues affecting neurologists and neurologic patients across the nation. The first day of the program is a communication and media workshop and the second day sends attendees to Capitol Hill, speaking on behalf of the AAN, to the elected policymakers themselves. According to Melissa Larson, Advocacy Development Manager for the AAN, "there were a record number of applicants to $\mathrm{NOH}$ in 2011 and this cohort will be the largest ever," demonstrating that more and more physicians are opting to pursue training in the realm of advocacy and policy.

For those with the interest but not the time, free Web seminars through disease-specific organizations are becoming an increasingly available option. One example is through the Parkinson's Action Network (PAN). The organization offers a 4-hour Webcast for 
physicians that coincides with PAN's 3-day advocacy forum in Washington, DC. The purpose of the Webcast is to educate physicians on how to become better advocates for their patients, learn about methods to secure research funding, and increase community support for patients with Parkinson disease.

THE PATIENT PROTECTION AND AFFORDABLE CARE ACT The ACA is an example of a policy change that will have a significant impact on neurologists in the United States. For example, the bill aims to shift care away from a fee-for-service model and toward a value-based payment system in which efficient and high-quality care is recognized and rewarded. Neurologists will have the opportunity to earn bonuses by participating in the Physician Quality Reporting Initiative and ACOs. ${ }^{3}$ Additional provisions relevant to neurologists include new imaging requirements, demonstration projects focusing on telemedicine and stroke care, loan repayment programs for residents/fellows, and the distribution of additional residency slots. Alongside these incentives, however, are provisions to control costs, which will likely result in changes to the current physician reimbursement formula. Beginning in 2015, the Independent Payment Advisory Board (IPAB), a 15-member board tasked with extending Medicare solvency, will make recommendations to Congress and to the President to reduce the growth rate if Medicare spending is expected to exceed predetermined targets. ${ }^{4-5}$ While the IPAB is prohibited from submitting proposals that would ration care, increase revenues, or change benefits, physician reimbursement is likely to be adversely affected. The interplay of these provisions and their ultimate impact on the delivery and quality of medical care are the daily focus of a health policy fellow.

DISCUSSION For current and future reforms to truly benefit the field of neurology, a new generation of physicians must be trained in health policy. Medical student curricula are incorporating health policy didactics and all neurology residents can apply to participate in advocacy programs such as PALF and NOH. Participation in programs such as these provide neurologists with a unique opportunity to acquire a new skill set focusing on patient advocacy and improved patient care. By engaging in the process, physicians become more skilled in the art of communication and policy navigation. These opportunities are the nexus of health science, policy, and politics and vital to providing the next generation of neurologists with the expertise needed to become effective leaders and advocates.

\section{AUTHOR CONTRIBUTIONS}

Dr. Zecavati: drafting/revising the manuscript, study concept or design, analysis or interpretation of data, acquisition of data. Dr. Song: drafting/ revising the manuscript, study concept or design, analysis or interpretation of data, acquisition of data. Dr. Giordano Farmer: drafting/revising the manuscript, acquisition of data.

\section{DISCLOSURE}

Dr. Zecavati was the 2009-2010 Kenneth M. Viste Public Policy Fellow and received an academic stipend from the American Academy of Neurology, the Child Neurology Society, and the American Neurological Association. Dr. Song and Dr. Giordano Farmer report no disclosures.

\section{REFERENCES}

1. Amery M. Public policy is at the heart of the American political system: you are what keeps it beating. Available at: www.aan.com/go/advocacy/active/viste. Accessed March 28, 2011.

2. Kaiser Foundation Summary of Health Policy Fellowships and Internships. Available at: http://www.kaiseredu.org/ Fellowships-and Internships.aspx. Accessed February 7, 2011.

3. The Patient Protection and Affordable Care Act: All CMS Provisions: As of September 24, 2010. Available at: www. cms.gov/LegislativeUpdate/downloads/PPACA.pdf. Accessed November 15, 2010.

4. The Patient Protection and Affordable Care Act and the Health Care and Education Reconciliation Act of 2010; Public Laws 111-148 and 111-152: Consolidated Print. Available at: http://www.ncsl.org/documents/health/ ppaca-consolidated.pdf. Accessed November 15, 2010.

5. Elmendort DW. Congressional Budget Office Cost Estimate for the Amendment in the Nature of a Substitute for H.R. 4872, Incorporating a Proposed Manager's Amendment Made Public on March 20, 2010: Congressional Budget Office. Available at: www.cbo.gov. Accessed November 15, 2010. 


\section{Neurology}

\section{Emerging Subspecialties in Neurology: Public policy fellowships \\ Nassim Zecavati, Sarah Song and Jill Giordano Farmer \\ Neurology 2011;77; e85-e87 \\ DOI 10.1212/WNL.0b013e318232ab77}

\section{This information is current as of October 10, 2011}

\section{Updated Information \&}

Services

Subspecialty Collections

Permissions \& Licensing

Reprints including high resolution figures, can be found at: http://n.neurology.org/content/77/15/e85.full

This article, along with others on similar topics, appears in the following collection(s):

Other Education

http://n.neurology.org/cgi/collection/other_education

Information about reproducing this article in parts (figures,tables) or in its entirety can be found online at:

http://www.neurology.org/about/about_the_journal\#permissions

Information about ordering reprints can be found online:

http://n.neurology.org/subscribers/advertise

Neurology ${ }^{\circledR}$ is the official journal of the American Academy of Neurology. Published continuously since 1951, it is now a weekly with 48 issues per year. Copyright Copyright $@ 2011$ by AAN Enterprises, Inc.. All rights reserved. Print ISSN: 0028-3878. Online ISSN: 1526-632X.

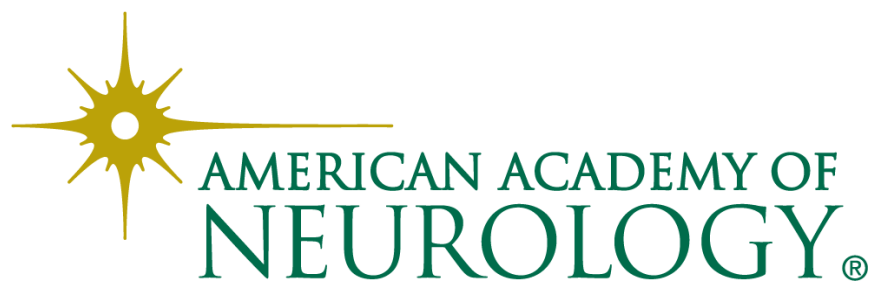

